\title{
Dance of the Cranes: Crane symbolism at Çatalhöyük and beyond
}

Nerissa Russell ${ }^{1} \&$ Kevin J. McGowan ${ }^{2}$

In this article, the authors reveal the symbolic role of cranes at Neolithic Çatalhöyük, Turkey. Worked bones of the Common Crane (Grus grus) are interpreted as coming from a spread wing used in dances, a ritual practice perhaps connected with the celebration of marriage.

Keywords: Neolithic, Anatolia, Çatalhöyük, birds, zooarchaeology

"Chryse has seen an omen. Cranes are dancers too; everyone knows the crane-dance. We'll be the Cranes." (Renault 1958:205)

\section{Cranes at Çatalhöyük}

Bird symbolism at Çatalhöyük, for those familiar with the results of the 1960 s excavations, is most likely to mean vultures. The paintings of Griffon Vultures (Gyps fulvus) pecking at headless corpses, and the heads of this same vulture mounted on walls with beaks protruding from plaster mounds interpreted by the excavator as breasts, make for some memorable images (Mellaart 1967:101, 126, 150, 166-168; Figures 14, 15, 47; Plates 28, 45-49). Our work on the bird bones from the renewed excavations at Çatalhöyük, along with finds from other sites of similar age, suggests that Common Cranes (Grus grus) were also a focus of symbolism and ritual.

Çatalhöyük is a tell site in the Konya Plain of central Anatolia composed of two mounds, the Chalcolithic West Mound and the Neolithic East Mound. Here we will discuss only the remains from the East Mound, which dates to approximately 7300-6200 cal BC (Cessford 2001). The site is famous for its large size (c.13 ha); its closely packed mudbrick houses, and the paintings and reliefs of animal parts found within those houses. It was first excavated in the 1960s by James Mellaart (1967), who uncovered a large number of houses, some of which contained spectacular art. The new project, directed by Ian Hodder, has since 1995 excavated a much smaller area with finer-grained recovery methods (Hodder \& Matthews 1998). All sediments from the new excavations are screened through $4 \mathrm{~mm}$ mesh, and substantial amounts are sampled for flotation. This procedure has permitted the recovery of a relatively large and varied assemblage of bird bones, with 387 specimens so far recorded from the Neolithic layers of the East Mound.

1 Department of Anthropology, Cornell University, Ithaca, NY 14853, USA (Email: nr29@cornell.edu)

2 Cornell Laboratory of Ornithology, Cornell University, Ithaca, NY 14853, USA

Received: 9 April 2002 Accepted: 15 October 2002 
Common Crane bones account for about two per cent of the bird bones identified (Russell $\&$ McGowan in press). Only one of the Common Crane specimens from the East Mound can reasonably be interpreted as dietary remains: a coracoid fragment from a midden deposit. Two Common Crane tarso-metatarsi (lower leg bones) have been worked into bone points (i.e., awls, perforators); these are the only cases of the use of bird bone among the 310 points recorded from the new excavations. Since both are from the left leg, and are in any case from levels widely separated in time (c. 500 years), they must come from two separate birds. While the number is small, their presence suggests a minor tradition of making points from this bone, perhaps for some particular purpose.

The remaining Common Crane bones from the East Mound derive from a single left wing found in a metre-wide space between a building and another narrow space (probably corresponding to Level VI or VII in Mellaart's scheme). With the wing were several other items that might be considered 'special': it was placed on top of a complete cattle horn core; slightly to the south lay two morphologically wild goat horn cores (inside Building 1 to the west of this space, thirteen morphologically wild goat horn cores were arrayed over a bin-like structure full of lentils), a dog head complete with mandibles and the second vertebra, and a stone macehead. These seem to have been deposited rapidly, probably as a single event, and are associated with the construction of Building 1 (Cessford in press).

Although it was not recognised in situ and was damaged in excavation (indicated by modern breaks and missing pieces), it is clear that in the ground this wing was complete from the distal humerus to the tip (see Figure 1). This part of the wing has very little flesh, but the large flight feathers are attached to it. In fact, it conforms closely to the portion used in

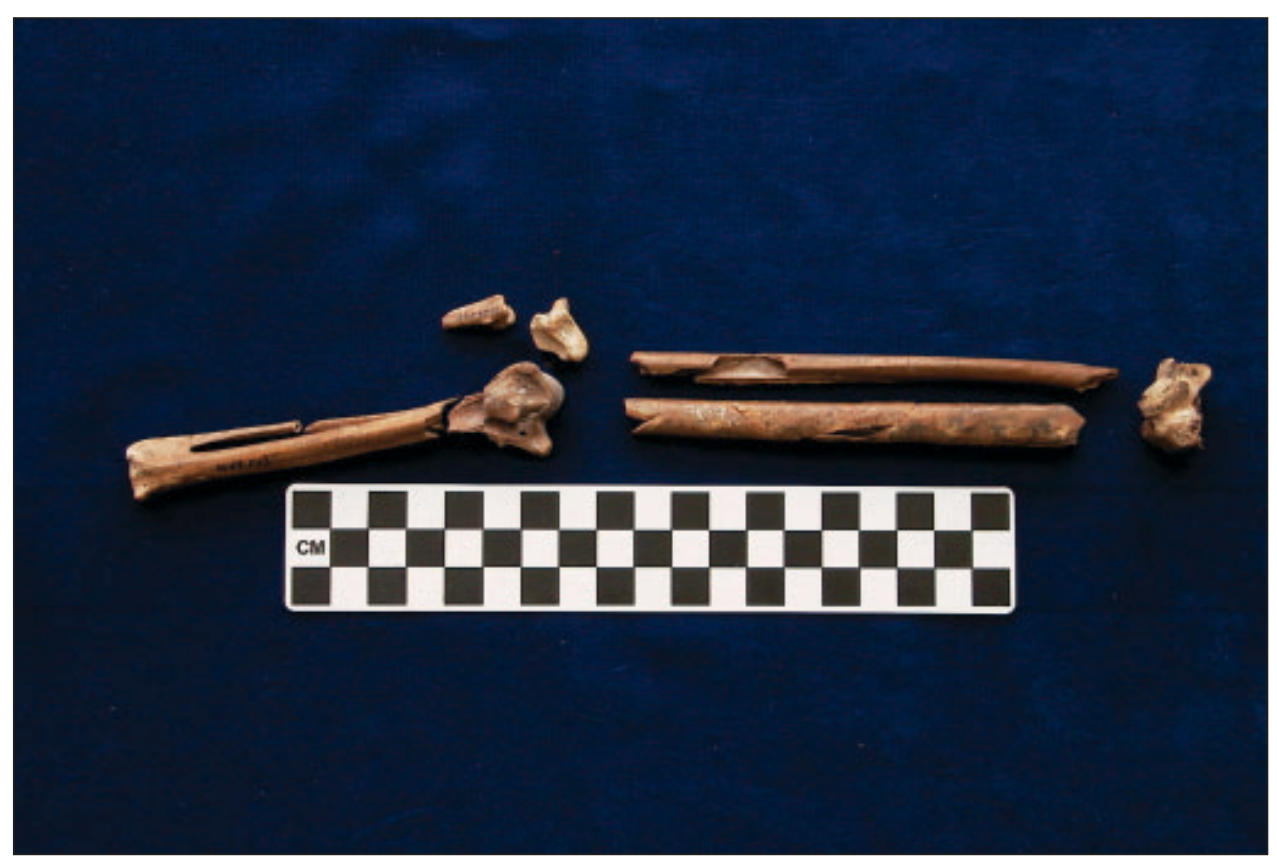

Figure 1. The Çatalhöyük crane wing, space 73, unit 1347. 


\section{Dance of the Cranes}

spread wing preparations in modern reference collections. With the skin and feathers on, it would thus resemble such a spread wing (see Figure 2).

Cut marks on the bones indicate that this was not simply butchery waste. Dismemberment cuts, designed to separate the wing at the joints, would be concentrated on or near the articular surfaces. Filleting cuts to remove the small amount of flesh between the radius and ulna would be shallow in depth and oriented longitudinally. One of the authors (KJM) has produced marks of this kind when filleting out these muscles during the preparation of a Sandhill Crane (Grus canadensis) spread wing. In fact, cut marks from butchery and processing, especially dismemberment marks, are quite rare at Çatalhöyük in general and totally absent on the bird bones. Aside from this wing, the only other cut marks on bird bones are the traces of manufacture on worked pieces (Russell \& McGowan in press).

The deepest and most numerous cuts on the wing are located in two clusters on the posterior side of the proximal shaft of the radius, in the interosseous space between the radius and ulna near the proximal end of this wing segment. The clusters are slightly separated, with one lying on the cranial and the other on the caudal side of the bone, indicating separate cutting actions entering from both sides of the wing. A few light cuts also appear on the dorsal (upper) side of the radius, an area where there is no flesh but a large flap of skin called the patagium, forming the forward edge of the wing. Two smaller and lighter sets of cuts also occur in the same region on the ulna, one facing into the interosseous space and the other on the outer side. All the cuts are transverse, and many are rather deep, unlike the light filleting cuts (see Figures 3 and 4). In sum, these cuts do not resemble either dismemberment or filleting cuts, the types that might be produced by processing for food. Rather, the cutting motions that would produce the marks would pierce a hole through the skin in a secure place between the bones in order to attach the wing to something. The few marks on the outer side of the bones may be stray marks from the first tentative cuts, or in the case of the cuts on the dorsal radius may derive from a second hole pierced through the patagium, so that a fibre could be run around both sides of the radius.

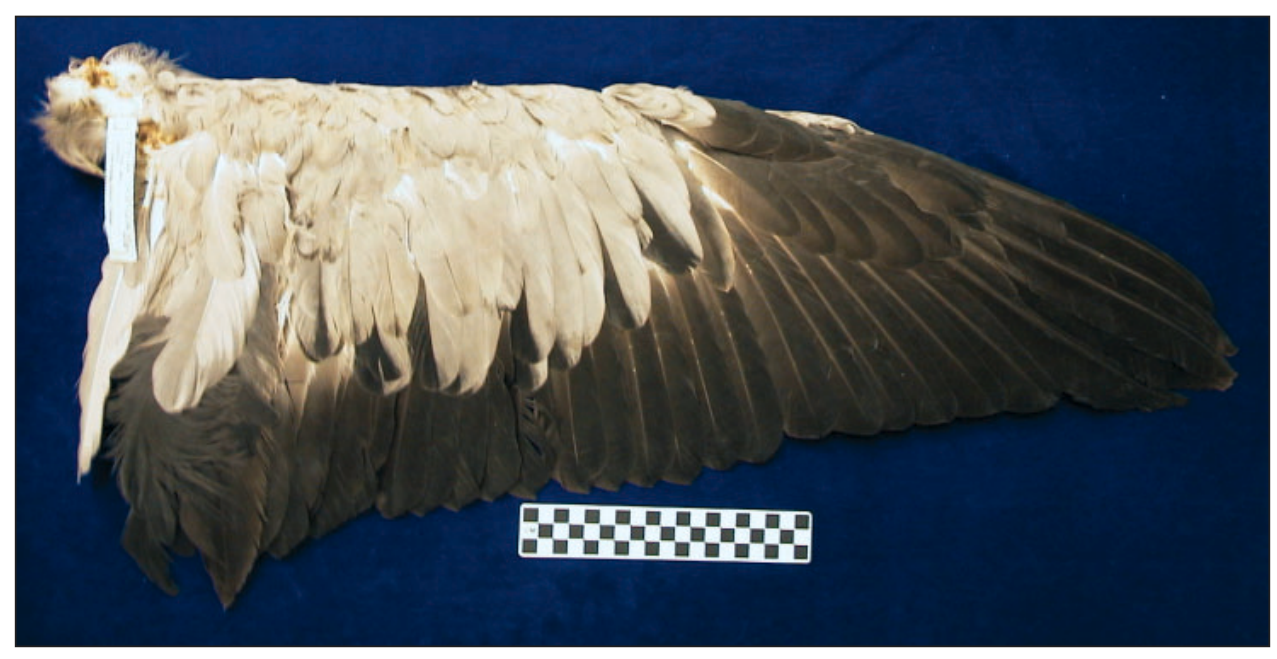

Figure 2. Common Crane spread wing, approximating the original appearance of the Çatalhöyük wing. Specimen provided by the Division of Birds, Smithsonian Institution. 
There are, of course, many things to which the wing could have been attached. It might have been hung from a pole or on a wall, for example. We believe that one of the most plausible uses is as a component of a costume used in ritual performances. It would be easy to pierce the patagium without touching the bone. The placement of the cuts in the interosseous space suggests that the perforation had to withstand stress from motion. Fibres run through the hole(s) attested by the cut marks could be used to attach the wing to the shoulder of a dancer. Such a costume would benefit from another hole further down the wing, in the vicinity of the distal radius and ulna. Unfortunately this part of the bone was less completely recovered. It would also be possible to make perforations further down without marking the bones.

In a little-known painting found in the last season of the 1960 s excavations at Çatalhöyük, two cranes face each other with heads raised (Mellaart 1966:190, Plates LXII-LXIII; see Figure 5). While the black colour is unrealistic, the shape of the birds makes this identification highly plausible. These appear along with various other animal and human figures on the south wall of shrine F.V.1 (Level V), whose north wall bore the famous bull painting. The male and female Common Cranes look alike, so we cannot tell whether this is meant to be a

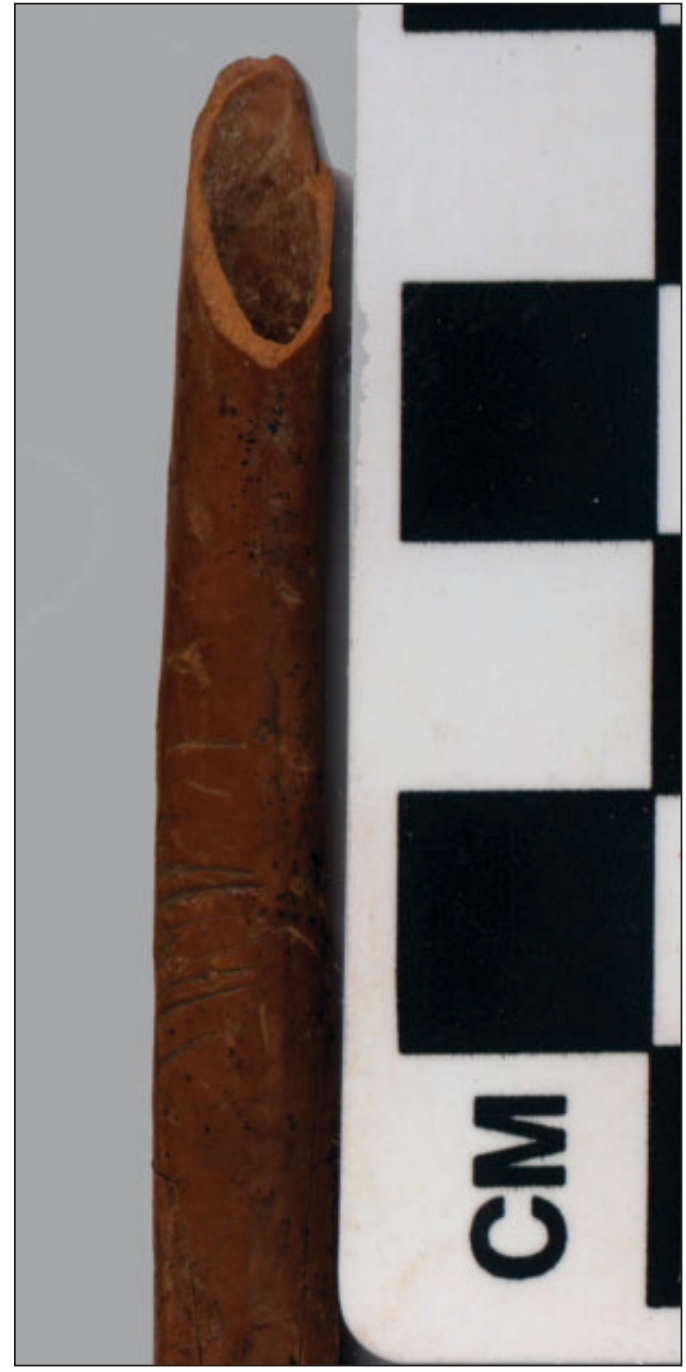

Figure 3. Cut marks on the radius of the Çatalhöyük crane wing.

mating pair. However, the facing pair of animals is a repeated theme in Çatalhöyük art (and elsewhere, e.g., Welté 1989) and for example is seen in a pair of onagers immediately below these cranes as well as the facing leopard reliefs. The cranes may thus be linked into a larger symbolic system of pairs or twins. On the east wall of this same room, Mellaart (1966:189, Plate LXIa) describes five dancing or gesticulating figures as wearing leopard-skins with tails embellished by black feathers, possibly crane. This identification was perhaps inspired by the black cranes on the south wall. There are many other birds that could produce black feathers, if that is indeed what is depicted, so the association is tenuous. 


\section{Dance of the Cranes}

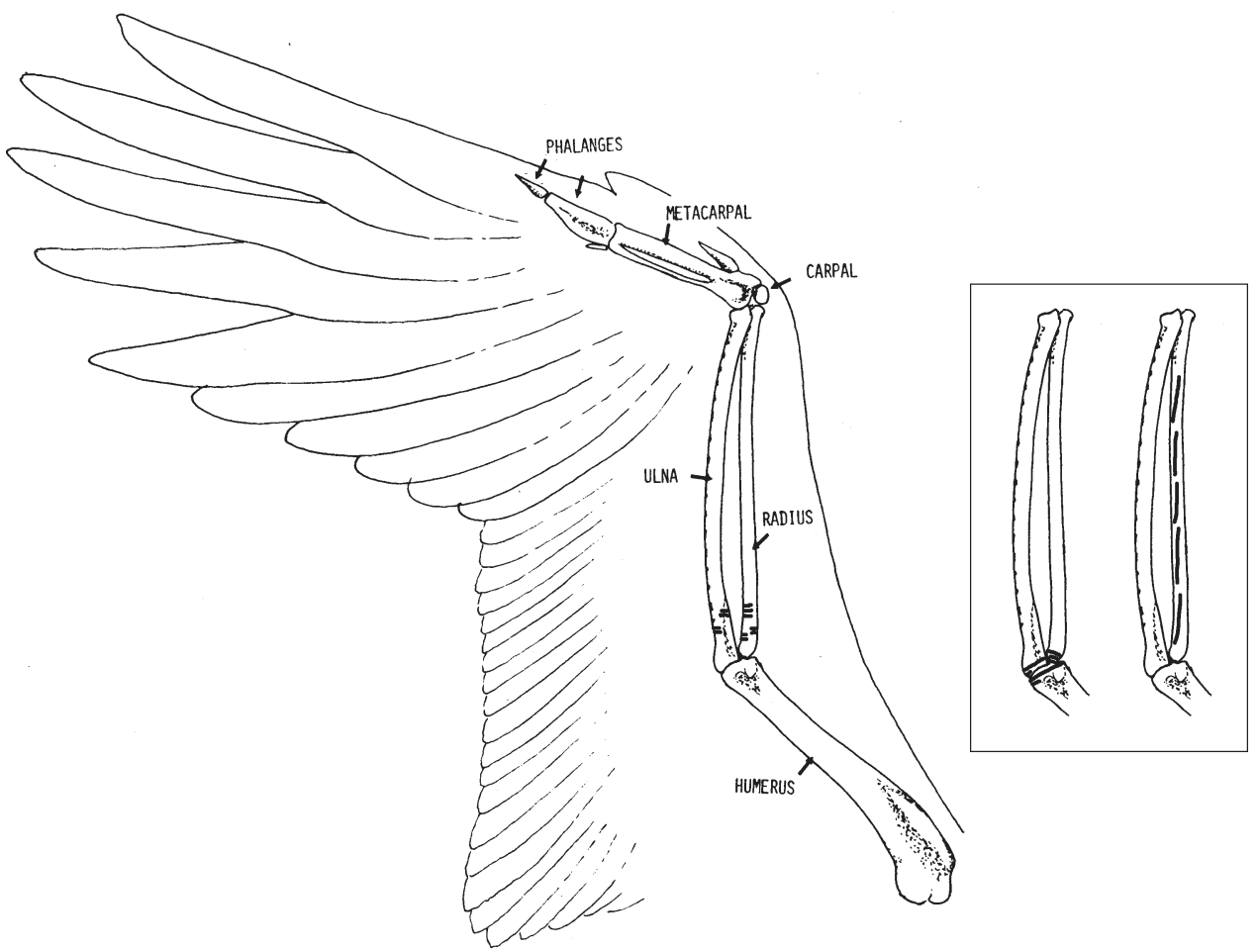

Figure 4. Schematic indication of the position of the cuts on the Çatalhöyük crane wing. The inset shows hypothetical dismemberment (left) and filleting (right) marks on the radius and ulna. Base drawing after Figure 1 in Cranes of the World (Johnsgard 1983).

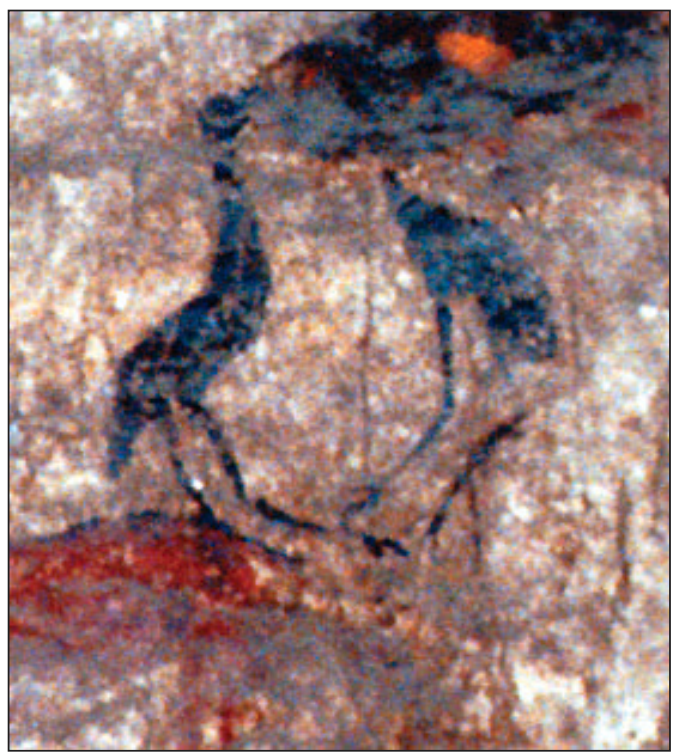

Figure 5. Detail of painting from the south wall of shrine F.V.1, with two cranes above a pair of onagers and below a fragmentary boar. Photograph courtesy of Pictures of Record, Inc.: Çatalhöyük, by James Mellaart. 


\section{Cranes elsewhere in the eastern Mediterranean}

While bird bone reports from prehistoric Anatolian sites are sparse, Common Cranes appear regularly on species lists from Neolithic and later sites (Buitenhuis 1985; von den Driesch \& Boessneck 1981). At these open sites, crane bones are unlikely to be introduced by nonhuman predators, so it is reasonable to assume that cranes were regularly killed in Neolithic Anatolia. Modern studies indicate that Common Cranes both breed, and, in larger numbers, winter in central Anatolia (Johnsgard 1983:228-231). They would surely have been more abundant in the past, since not only have Common Crane populations in general declined in recent centuries, but also the currently rather arid Konya Plain was much wetter in the Neolithic, and would have provided better habitat.

Common Crane has also been found at PPNB (pre-pottery Neolithic B) Jericho (Tchernov 1993), at early Neolithic Grotta dell'Uzzo on Sicily, and, intriguingly, together with vulture at Bronze Age La Starza in southern Italy (Albarella 1997). Albarella argues that while young crane is tasty and was prized in medieval Europe (see also von den Driesch \& Boessneck 1981:58; Pegge 1773; Salisbury 1994:53-54), adult crane meat was tough and unappealing. He suggests that the crane and vulture were instead hunted for their feathers. (This may well be, but one of the authors (KJM) has had occasion to eat adult Sandhill Crane and found it quite palatable. In any case, we should be cautious in attributing modern tastes to prehistoric people - the inhabitants of Çatalhöyük seem to have been particularly fond of Eurasian Coot [Fulica atra], now widely considered muddy and all but inedible). However, the evidence from Çatalhöyük supports hunting for more than just culinary motives.

Nor is Çatalhöyük unique in its depiction of cranes. House 17 at Bouqras, a late PPNB/early Ceramic Neolithic site in the Euphrates valley of south-east Syria that is approximately contemporary with Çatalhöyük, contained a frieze that originally bore at least 15 painted and two incised creatures identified as cranes, all facing to the left (Clason 1989/90). A number of carved stone stelae have been found inside the Schlangenpfeilergebäude (snake pillar building) at the PPNA/B site of Göbekli Tepe in south-eastern Turkey; this building appears to be $c .1500$ years earlier than the beginning of the Çatalhöyük sequence (Kramer \& Schmidt 1998). One of these, with a bucranium (abstracted cattle head) on the narrow side, has a series of large carved animals on one of the broad sides (Hauptmann 1999:79, Figure 22). Schmidt (1999), in consultation with zooarchaeologists Angela von den Driesch and Joris Peters, identifies these as bull (on the basis of its posture, apparently ready to charge - there is no morphological marking as male), a fox and crane. It is interesting to note that the Çatalhöyük crane wing occurs with (female) cattle and dog remains. A small fragment of fox bone was also recovered from this area but is probably of no special significance. This raises the possibility of an enduring mythic association of cattle, canids and cranes in Neolithic Anatolia.

Although Çatalhöyük has pottery in all but its earliest levels, it is chronologically equivalent to the late PPNB. Thus these three sites belong to a roughly contemporary horizon, with Göbekli Tepe rather earlier than the other two (Aurenche et al. 2001). All of these sites have a variety of animal imagery. Only at Bouqras could the cranes perhaps be said to be a dominant theme, but here they are the subject of the only preserved painting, while the other animals are represented as figurines (Clason 1993). Thus cranes seem to be a minor but consistent component of the late PPNA/PPNB symbolic world (Verhoeven 2002). We may wonder whether there was a shared crane myth that is evoked in these depictions. 


\section{Dance of the Cranes}

\section{Why cranes?}

Why should cranes have particular symbolic significance? Cranes of 14 species are found throughout most of the world, and have attracted attention in most places that they occur. In historically known cultures, cranes have been regarded as symbols of longevity, fidelity, filial piety, femininity, wisdom or wiliness, vigilance, changing seasons (linked to their migration) and, through association with the sun, with fertility and renewal and hence happiness and good fortune (Armstrong 1943; Balzer 1996; Hill Tout 1904; Johnsgard 1983:70-73; Rowland 1978; Toynbee 1973:243-245). The Celts seem to have been unusual in associating them with negative power and bad luck (Ettlinger 1943). They were sacrificed along with horses in the Vedic period, apparently because of their link to the sun and fertility (Armstrong 1943:75).

We suspect that much of the appeal of cranes lies in their striking similarities to people. Not only are they bipedal and of a size that approximates a human, standing $c .120 \mathrm{~cm}$ high in the case of the Common Crane (Snow et al. 1998:511), but their lifespan is comparable to that of humans, in some cases more than 40 years (Johnsgard 1983:57). Moreover, their social structure is not unlike ours. They are social birds, forming sizeable flocks outside of the nesting season, but the building blocks of crane society are nuclear families. Cranes form lasting, monogamous pairs, and young cranes have an extended period of juvenile dependency. They tend to move in family groups, and young cranes are easily distinguished from adults, so that this structure is readily observable. Their unusually long, coiled trachea enables cranes to emit a call often described as bugling or trumpeting, and usually perceived as sounding as though it were produced by a musical instrument (Johnsgard 1983).

Perhaps most importantly, cranes dance. The function of the dancing is not well understood, but is clearly social and seems to diffuse tensions. It is performed by breeding pairs, but also by whole groups of cranes throughout the year. When one crane starts, others tend to join in. The dance can also be stimulated by a human imitating it, or even by the approach of a human. All crane species have some form of dance. In the Common Crane, it takes the form of marching stiff-legged, running and leaping into the air with spread and beating wings, bowing, pirouetting, stopping and starting, and throwing and sometimes catching twigs. It may be performed in a roughly circular formation, which has particularly impressed many human viewers (Johnsgard 1983:14, 235; Snow et al. 1998:513-514). Pliny (1938) describes tamed cranes performing dances for human entertainment, moving in circles and taking turns dancing.

Since the cranes, already human-like in other aspects, appear to dance much as humans do, it is not surprising that people of many times and places have imitated cranes in their own dances. Perhaps the best known crane dance in the West is that performed by Theseus and his companions when they landed in Delos after slaying the Minotaur and escaping from Crete (Plutarch 1914:Theseus XXI). Crane dances are also known from the Ostiaks of Siberia, who wore crane skins for the occasion, which was apparently a shamanic performance (Armstrong 1943:73; Balzer 1996); from ancient Chinese funerals; from Australian corroborees (Johnsgard 1983:73); from Okinawan harvest festivals (Glacken 1953); and among the Ainu of Japan (St. John 1873) and the BaTwa of southern Africa (Campbell 1914:79).

Indeed the crane dance is so widespread that the author of what is to our knowledge the only previous scholarly article on human crane dances, which appeared in this journal 60 
years ago, took it as evidence for worldwide diffusion of a ritual complex from the Near East (Armstrong 1943). It seems more likely that the nearly worldwide distribution of the crane dance mirrors the nearly worldwide distribution of cranes (all continents except for South America and Antarctica; Armstrong 1943:3), and has arisen independently in many times and places. We are not, therefore, proposing that the origin of later crane dances in the Mediterranean and beyond lies at Çatalhöyük, but merely that many different human societies have been moved to imitate the dance of cranes.

\section{Conclusions}

We would suggest that the most probable use of the Çatalhöyük crane wing is as part of a costume worn during a crane dance. The inhabitants of Çatalhöyük clearly would have had the opportunity to see cranes dance, and they are likely to have been as impressed by it as other people have been. The crane remains and their depiction in a wall painting shows that they were held in special regard.

There is perhaps some supporting evidence from the art for this kind of dance. First, one of the vulture paintings, from shrine VII.21 (Level VII), appears to show the vultures with human legs, in contrast to the other two sets of vulture paintings that clearly depict birds' legs (Mellaart 1967:167, Figures 14-15). Mellaart suggests this may portray priests or priestesses wearing vulture costumes for a funerary ritual. If so, at least the idea of performing in bird costume would have been present. More tenuously, a damaged painting from shrine E.IV.1 (Level IV), part of which is interpreted by Mellaart as a person carrying two severed heads, also has a fragmentary image that looks very like a figure with some sort of clothing on the torso and a large, outstretched white wing. Mellaart describes this as an unintelligible group of lines, and he presents it only in the form of a transcription, rather than a photograph (Mellaart 1967:168, Plate 51). Thus it is hard to tell whether the wing shape is original or was fortuitously produced by damage.

More broadly, Garfinkel (1998) argues on the basis of representations of dance scenes that dance, and specifically dances stressing communal unity, becomes a dominant feature of Near Eastern social life at this period. Garfinkel identifies only one dance scene at Çatalhöyük: a plaque Mellaart (1967:148, Plate 83) describes as a depiction of sacred marriage and the resulting mother and child, but which Garfinkel believes shows a couple dancing. This stands in contrast to most Neolithic dance scenes, which show circle dances of the type more likely to be performed by crane dancers. Garfinkel analyses only anthropomorphic dancing figures. However, applying his criteria to the Bouqras frieze, the repeated figures in the same posture, evenly spaced and all facing the same direction, would indicate that this is a depiction of cranes dancing; although the posture of the birds is not one of the unmistakable dance positions.

What might have been the context and meaning of a crane dance? We have seen that cranes are often associated with fertility and renewal, through their links with changing seasons and the solar associations of their circular dance patterns (not because of their own fertility, which is rather low). It is unclear that the inhabitants of Çatalhöyük would have made this association, however. Sun symbolism is not obvious in the copious art, and since Common Cranes wintered as well as bred in the area, their seasonal association would not be as strong as it is in Europe, where they depart for the winter. Still, it is tempting to imagine a vulture dance of death, and a crane dance of life or rebirth. 


\section{Dance of the Cranes}

Given their monogamy and careful parental care, cranes might be associated with successful marriage. Since dances are performed both by mating pairs and by whole flocks, a crane dance might be especially appropriate at a wedding, when a couple is joined and recognised by the community. Contextually, the crane wing is associated with the construction of a house, which may or may not have been coincident with a marriage. It seems to form part of a deposit of symbolically charged objects, which may be paraphernalia from a ritual connected to the inauguration of this house. Presumably the costume included both wings, but there is no trace of the right wing here. Nor is it to be found in the similar between-wall space on the west end of Building 1. Unfortunately the areas to the north and south have not been excavated. Perhaps some of the paraphernalia had to stay with the house, the rest (one wing, one cattle horn) to go elsewhere or to be destroyed. This narrow space would have been difficult to reach, accessible only by climbing down $c .2$ metres from the adjacent roof. Thus while the crane dance is likely to have been a public event, the deposition of the wing and other materials would have been much more private.

The parallels between cranes and humans could lead to a belief that cranes are reborn humans, or the ancestors of humans. Perhaps for this reason, cranes are popular totems; where clans carry animal names, there is very often a Crane clan. Thus the crane dance might re-enact a myth of human origins, or of clan origins. The association with the house might be one of ancestry. We must note, though, that three other animals (cattle, goat, dog) are equally associated with it in this deposit.

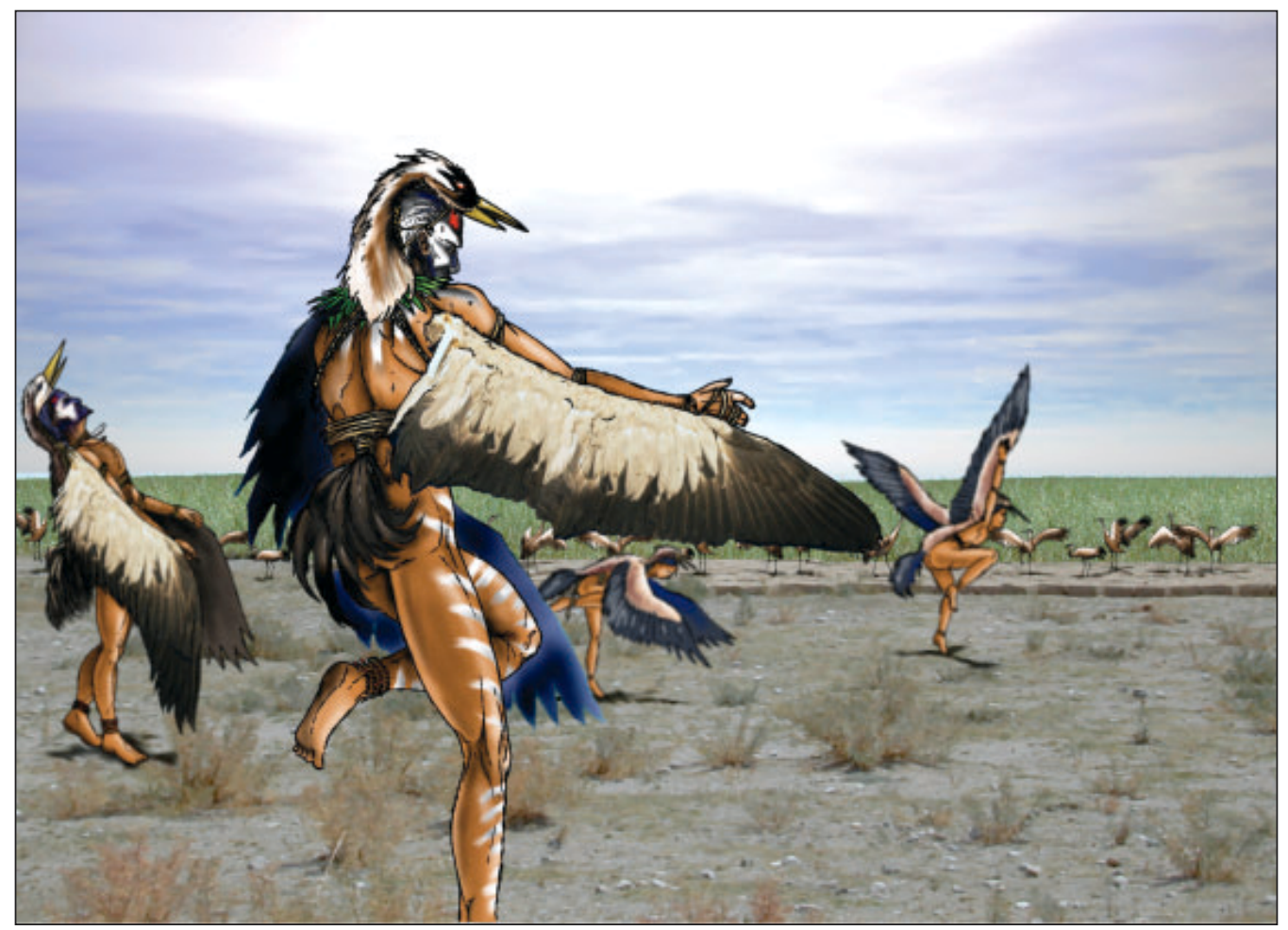

Figure 6. An imagined crane dance at Çatalhöyük, by John-Gordon Swogger. 
Whatever the specific meaning, the crane dance, performed by winged dancers whose athletic leaps and turns we can only imagine, must have been a breathtaking experience (see Figure 6). It is useful to remember that bulls are not the only animal symbol in the Neolithic of the Near East, but rather one of many celebrated in myth, ritual, and art. A complete aurochs horn core is hard to miss, but the archaeological remains of bird wings are subtler. Close study of the faunal remains from other Anatolian Neolithic sites may reveal further evidence of ancient rituals as well as ancient diet.

\section{Acknowledgements}

The crane and other Çatalhöyük bird bones were identified with the aid of the reference collections of the Cornell University Museum of Vertebrates and the Division of Birds at the Smithsonian Institution. We thank James Dean for providing access to the latter and the spread wing specimen. Craig Cessford has been especially helpful in working out the stratigraphic relations of the crane remains at Çatalhöyük, as well as offering insightful comments on an earlier draft of this article. The thoughtful comments of two anonymous reviewers have led to substantial improvements in this published version.

\section{References}

Albarella, U. 1997. Crane and vulture at an Italian Bronze Age site, International Journal of Osteoarchaeology 7(4): 346-349.

Armstrong, E.A. 1943. Crane dance in East and West, Antiquity 17: 71-76.

Aurenche, O., P. Galet, E. RéGagnon-Caroline \& J. Évin. 2001. Proto-Neolithic and Neolithic cultures in the Middle East -The birth of agriculture, livestock raising and ceramics: A calibrated 14C chronology, 12,500-5500 cal BC, Radiocarbon 43(3): 1191-1202.

BAlzer, M.M. 1996. Flights of the sacred: Symbolism and theory in Siberian shamanism, American Anthropologist 98(2): 305-318.

Buttenhuis, H. 1985. Preliminary report on the faunal remains of Hayaz Höyük from the 1979-1983 seasons, Anatolica 12: 61-74.

Campbell, D. 1914. A few notes on Butwa: An African secret society, Man 14: 76-81.

CESsFord, C. 2001. A new dating sequence for Çatalhöyük, Antiquity 75(290): 717-725.

Cessford, C. in press. The North area, in I. Hodder, (ed.) Catalhöyük 1995-1999: Excavations in the North, South and Kopal Areas. Cambridge: McDonald Institute for Archaeological Research. McDonald Institute Monographs.

Clason, A.T. 1989/90. The Bouqras bird frieze, Anatolica 16: 209-213.

-1993. The hedgehog, the hare, the bull and the tortoise, in H. Buitenhuis \& A. T. Clason, (eds.), Archaeozoology of the Near East: Proceedings of the First International Symposium on the Archaeozoology of South-western Asia and Adjacent Areas: 46-51. Leiden: Universal Book Services.
Driesch, A., Von Den \& J. Boessneck. 1981. Reste von Haus- und Jagdtieren aus der Unterstadt von Bogazköy-Hattusa: Grabungen 1958-1977. Berlin: Gebr. Mann. Bogazköy-Hattusa, No. 11.

Ettlinger, E. 1943. Omens and Celtic warfare, Man 43: 11-17.

Garfinkel, Y. 1998. Dancing and the beginning of art scenes in the early village communities of the Near East and south-east Europe, Cambridge Archaeological Journal 8(2): 207-237.

GLaCKen, C.J. 1953. Studies of Okinawan Village Life. Washington, DC: Pacific Science Board, National Research Council.

Hauptmann, H. 1999. The Urfa region, in N. Basgelen \& M. Özdogan, (eds.), Neolithic in Turkey: The Cradle of Civilization - New Discoveries: 65-86. Istanbul: Arkeoloji ve Sanat Yayınıları.

Hill Tout, C. 1904. Report on the ethnology of the Siciatl of British Columbia, a coast division of the Salish stock, Journal of the Anthropological Institute of Great Britain and Ireland 34: 20-91.

Hodder, I. \& R.J. MatTHEws. 1998. Çatalhöyük: The 1990s seasons, in R. J. Matthews, (ed.) Ancient Anatolia: Fifty Years' Work by the British Institute of Archaeology at Ankara: 43-51. Ankara: British Institute of Archaeology at Ankara.

JOHNSGARD, P.A. 1983. Cranes of the World. Bloomington: Indiana University Press.

Kramer, B. \& K. Schmidt. 1998. Two radiocarbon dates from Göbekli Tepe, south eastern Turkey, Neo-Lithics: A Newsletter of SouthWest Asian Lithics Research 3: 8-9.

MellaART, J. 1966. Excavations at Çatal Hüyük, 1965: Fourth preliminary report, Anatolian Studies 16: 165-191. 


\section{Dance of the Cranes}

-1967. Çatal Hüyük: A Neolithic Town in Anatolia. London: Thames \& Hudson.

PegGe, S. 1773. A dissertation on the crane, as a dish served up at great tables in England, Archaeologia 2: 171-176.

PLINY. 1938. Natural History. H. Rackham, transl. Cambridge: Harvard University Press.

PlutarCH. 1914. Plutarch's Lives with an English Translation. B. Perrin, transl. Cambridge: Harvard University Press.

Renault, M. 1958. The King Must Die. New York: Pantheon.

Rowland, B. 1978. Birds with Human Souls: A Guide to Bird Symbolism. Knoxville: University of Tennessee Press.

Russell, N.\& K.J. MCGOWAN in press. The Çatalhöyük bird bones, in I. Hodder, (ed.) Çatalhöyük 19951999: Subsistence. Cambridge: McDonald Institute for Archaeological Research. McDonald Institute Monographs.

SAlisbury, J.E. 1994. The Beast Within: Animals in the Middle Ages. New York: Routledge.
SchmidT, K. 1999. Frühe Tier- und Menschenbilder vom Göbekli Tepe, Istanbuler Mitteilungen des Deutschen Archäologischen Instituts 49: 5-21.

Snow, D., C.M. Perrins, R. Gillmor, B. Hillcoat, C.S. Roselaar, D. Vincent, D.I.M. Wallace \& M.G. WiLson. 1998. The Birds of the Western Paleartic. Concise edition. Oxford: Oxford University Press.

ST. John, H.C. 1873. The Ainos: Aborigines of Yeso, Journal of the Anthropological Institute of Great Britain and Ireland 2: 248-254.

TChernov, E. 1993. Exploitation of birds during the Natufian and early Neolithic of the southern Levant, Archaeofauna 2: 121-143.

Toynbee, J.M.C. 1973. Animals in Roman Life and Art. London: Thames \& Hudson.

Verhoeven, M. 2002. Ritual and ideology in the PrePottery Neolithic B of the Levant and southeast Anatolia, Cambridge Archaeological Journal 12(2): 233-258.

Welté, A.C. 1989. An approach to the theme of confronted animals in French Palaeolithic art, in H. Morphy, (ed.) Animals into Art: 215-235. London: Unwin Hyman. 